\title{
PENGEMBANGAN TEKNIK PEMBELAJARAN SERVIS FOREHAND BULUTANGKIS BAGI SISWA PUTRA SEKOLAH MENENGAH ATAS
}

\author{
Silvi Aryanti' ${ }^{1)}$, Ahmad Richard Victorian' ${ }^{2)}$, dan Herri Yusfi ${ }^{3)}$ \\ ${ }^{1,2,3}$ Program Studi Pendidikan Jasmani dan Kesehatan, Fakultas Keguruan dan Ilmu Pendidikan, Universitas Sriwijaya \\ ${ }^{1,2,3}$ Jl. Raya Palembang Prabumulih Km. 32, Indralaya Ogan Ilir, Kode Pos 30662 \\ E-mail : silviaryanti@fkip.unsri.ac.id ${ }^{1)}$,richarda2_060@ymail.com ${ }^{2}$, herri_yusfi@yahoo.com ${ }^{3)}$
}

\begin{abstract}
ABSTRAK
Penelitian ini bertujuan untuk mengembangkan teknik pembelajaran servis forehand panjang bulutangkis bagi siswa putra sekolah menengah atas sehingga dapat mencapai kompetensi. Metode yang digunakan yaitu penelitian dan pengembangan ( $\mathrm{R}$ n D) dengan model ADDIE. Tahapan dalam penelitian ini yaitu analysis, design, development or production, implementation or delivery and evaluations. Responden dalam penelitian adalah siswa putra kelas X SMA Negeri 14 Palembang. Hasil penelitian ini berupa buku pedoman servis forehand panjang bulutangkis. Berdasarkan hasil validasi ahli permainan bulutangkis diperoleh presentase sebesar 67,85\% dalam kategori "cukup layak".Validasi dari ahli Pendidikan Jasmani, Olahraga dan Kesehatan (PJOK) diperoleh persentase sebesar 69,64 dalam kategori “cukup layak".Implikasi penelitian ini bahwa teknik pembelajaran servis forehand panjang dapat digunakan untuk pembelajaran bulutangkis.
\end{abstract}

Kata Kunci: Pengembangan, Teknik Pembelajaran, Permainan Bulutangkis

\section{PENDAHULUAN}

Pendidikan jasmani merupakan bagian dari program pendidikan secara keseluruhan. Berdasarkan Undang-Undang Republik Indonesia Nomor 3 tahun 2005 tentang sistem keolahragaan nasional bahwa pendidikan jasmani dan olahraga dilaksanakan sebagai bagian dari proses pendidikan yang teratur dan berkelanjutan untuk memperoleh pengetahuan, kepribadian, keterampilan, kesehatan dan kebugaran jasmani. Paturusi (2012) tujuan pendidikan jasmani dan olahraga adalah memberikan kesempatan pada siswa untuk mempelajari berbagai kegiatan uang membina, mengembangkan potensi meliputi aspek fisik, mental, sosial, emosional dan moral.

PJOK di sekolah bertujuan untuk mengembangkan aspek kebugaran jasmani, keterampilan gerak, keterampilan berfikir kritis, keterampilan sosial, penalaran, stabilitas emosional, tindakan moral, pola hidup sehat dan pengenalan lingkungan bersih melalui pembekalan pengalaman belajar menggunakan aktivitas jasmani yang dilakukan secara sistematis dilandasi nilainilai keimanan dan ketaqwaan kepada Tuhan Yang Maha Esa. Kompetensi Inti 3 (pengetahuan) pada kurikulum 2013 PJOK yaitu memahami, menerapkan, menganalisis pengetahuan faktual, konseptual, prosedural berdasarkan rasa ingin tahu tentang ilmu pengetahuan, teknologi, seni,budaya, dan humaniora dengan wawasan kemanusiaan, kebangsaan, kenegaraan, danperadaban terkait penyebab fenomena dan kejadian, sertamenerapkan pengetahuan prosedural pada bidang kajian yang spesifik sesuai dengan bakat dan minatnya untuk memecahkan masalah. Kompetensi dasar 3.2 yaitu menganalisis keterampilan gerak salah satu permainan bola kecil untuk menghasilkan koordinasi gerak yang baik. Matapelajaran dalam Pendidikan jasmani, olahraga, dan kesehatan (PJOK) terdapat materi pembelajaran permainan bola kecil yaitu permainan bulutangkis.

Materi yang diajarkan dalam bulutangkis salah satunya adalah servis. Servis sangatlah penting dalam permainan bulutangkis. Nurhasan, dkk (2015) pukulan servis merupakan pukulan awal yang menerbangkan shuttlecock ke bidang lapangan lawan secara diagonal. Aturan permainan bulutangkis, servis merupakan modal awal untuk memenangkan pertandingan. Seorang pemain tidak bisa mendapatkan angka apabila tidak bisa melakukan servis dengan baik. Juhanis (2012) servis bulutangkis yang baik dan menyulitkan lawan mengembalikan shuttlecock memerlukan kemampuan gerakan yang terkoordinir. Bertujuan untuk kesatuan gerakan servis yang benar. Servis bulutangkis dibagi menjadi servis forehand dan servis pendek backhand. Permainan tunggal sering menggunakan servis forehand panjang dan salah satu yang harus dikuasai. Stephani Yane (2017) pembelajaran bulutangkis di sekolah yang diajarkan kepada siswa diarahkan agar dapat melakukan servis dengan baik, salah satunya adalah melakukan servis panjang. Purnama (2010) Servis panjang termasuk ke dalam jenis pukulan underhand stroke yaitu pukulan dilakukan dengan ayunan raket dari bawah ke atas. Servis panjang sering digunakan dalam permainan tunggal, dengan laju shuttlecock yang melambung ke arah lapangan lawan sehingga permainan akan terjadi rally .

Berdasarkan observasi di lapangan siswa putra kelas $\mathrm{X}$ SMA Negeri 14 Palembang mengalami kesulitan dalam memahami materi tentang servis forehand panjang bulutangkis dan saat praktek siswa putra belum menguasai. Guru memberikan hanya 1-2 teknik dan 
langsung memberikan instruksi kepada siswa untuk melaksanakan servis forehand panjang dilapangan bulutangkis tanpa adanya tahapan-tahapan untuk mempermudah siswa sehingga tujuan pembelajaran tidak seperti yang diharapkan. Mencapai tujuan pembelajaran, seorang guru harus memiliki teknik pembelajaran yang baik.

Menurut Gerlach dan Ely pengertian teknik adalah jalan, alat, atau media yang digunakan oleh guru untuk mengarahkan kegiatan peserta didik kearah tujuan yang ingin dicapai (Hamzah B Uno, 2009). Abdul Halik (2013) teknik pembelajaran merupakan cara yang dilakukan seorang pendidik dalam mengimplementasikan suatu media atau metode. Pendidik yang sedang mengajar di kelas, maka yang akan terlihat pada kegiatan pendidik dan peserta didik itu adalah teknik pembelajaran. Oleh sebab itu, pemilihan teknik pembelajaran yang tepat sangat dibutuhkan untuk meningkatkan pencapaian hasil belajar siswa. Teknik pembelajaran dalam penerapannya dilakukan sesuai dengan kebutuhan siswa. Hal ini karena masing-masing teknik pembelajaran memiliki tujuan, prinsip, dan tekanan yang berbeda-beda. Pemilihan pengembangan teknik pembelajaran yang tepat dapat membantu menyampaikan pesan dengan benar, efektif, efisien, dapat menciptakan dan memperkaya pengalaman belajar, menghadirkan gambaran sebuah kejadian sedekat atau senyata mungkin, serta mampu meningkatkan keaktifan dan keterampilan siswa.

Stephani Yane (2016) hasil penelitian yang diperoleh adanya peningkatan keterampilan servis panjang bulutangkis yang cukup baik yaitu pada siklus I dengan nilai rata-rata 60,20 dalam presentase $35,71 \%$, sedangkan nilai rata-rata pada siklus II adalah 74,15 dalam presentase $78,57 \%$. Bentuk penelitian yang digunakan yaitu penelitian tindakan kelas dengan dua siklus. Oleh sebab itu, dengan mengacu pada penelitian terdahulu maka penelitian ini pada teknik pembelajaran servis forehand panjang bulutangkis bagi siswa putra kelas $\mathrm{X}$ Sekolah Menengah Atas. Metode penelitian menggunakan penelitian dan pengembangan dengan model ADDIE yaitu analysis, design, development, implementation, dan evaluation. Penelitian ini diharapkan menghasilkan sebuah teknik pembelajaran yang valid dan efektif untuk servis forehand panjang bulutangkis. Berdasarkan pernyataan di atas, maka akan dilakukan penelitian terhadap pengembangan teknik pembelajaran servis bulutangkis pada siswa putra kelas $\mathrm{X}$ sekolah menengah atas.

\section{RUANG LINGKUP}

Permasalahan penelitian ini mencakup sebagai berikut:

1. Cakupan Permasalahan

Bagaimana menghasilkan teknik pembelajaran servis forehand panjang bulutangkis bagi siswa putra kelas $\mathrm{X}$ sekolah menengah atas yang valid dan efektif.
2. Batasan-batasan penelitian

Batasan dalam penelitian pengembangan ini adalah sebagai berikut:

1) Teknik pembelajaran dilakukan pada materi servis forehand panjang bulutangkis

2) Subjek penelitian ini menggunakan siswa putra kelas X Sekolah Menengah Atas Negeri 14 Palembang.

3) Hasil penelitian adalah sampai pada keterampilan servis forehand panjang bulutangkis

3. Rencana hasil yang didapatkan

Hasil Penelitian Produk Pengembangan Teknik Pembelajaran Servis Forehand Panjang Bulutangkis. Hasil tahap pengembangan teknik pembelajaran servis forehand panjang bulutangkis bagi siswa putra kelas $\mathrm{X}$ SMA menggunakan model ADDIE yaitu sebagai berikut: 1) Analisis

Tahapan yang pertama yaitu analisis yaitu tahap yang dilakukan untuk menganalisis perlunya pengembangan teknik pembelajaran servis forehand panjang bulutangkis. Adapun temuan lapangan yang didapatkan yaitu sebagai berikut:

Tabel 1. Hasil Analisis Kebutuhan dan Temuan Lapangan

\begin{tabular}{|c|c|c|}
\hline No. & Butir Pertanyaan & Temuan \\
\hline 1 & $\begin{array}{l}\text { Apakah pemberian materi } \\
\text { teknik pembelajaran servis } \\
\text { forehand panjang } \\
\text { bulutangkis kelas X oleh } \\
\text { guru disampaikan secara } \\
\text { bervariasi? }\end{array}$ & $\begin{array}{l}\text { Pemberian materi } \\
\text { pembelajaran oleh guru } \\
\text { disampaikan kurang } \\
\text { variasi dan monoton }\end{array}$ \\
\hline 2 & $\begin{array}{l}\text { Apakah tersedia sarana } \\
\text { dan prasarana bulutangkis } \\
\text { untuk melakukan servis } \\
\text { forehand panjang kelas } \mathrm{X} \text { ? }\end{array}$ & $\begin{array}{l}\text { Cukup baik karena } \\
\text { tersedianya sarana dan } \\
\text { prasarana bulutangkis } \\
\text { seperti lapangan, net, } \\
\text { raket, dan shuttle cock } \\
\text { untuk menunjang teknik } \\
\text { pembelajaran servis } \\
\text { forehand panjang }\end{array}$ \\
\hline 3 & $\begin{array}{l}\text { Bagaimana penerapan } \\
\text { teknik pembelajaran servis } \\
\text { forehand panjang } \\
\text { bulutangkis kelas } \mathrm{X} \text { ? }\end{array}$ & $\begin{array}{l}\text { Cukup baik namun } \\
\text { kurang bervariasi dalam } \\
\text { pelaksanaanpembelajaran } \\
\text { teknik pembelajaran } \\
\text { servis forehand panjang }\end{array}$ \\
\hline 4 & $\begin{array}{l}\text { Bagaimana motivasi siswa } \\
\text { saat pembelajaran materi } \\
\text { servis forehand panjang } \\
\text { bulutangkis kelas } \mathrm{X} \text { ? }\end{array}$ & $\begin{array}{l}\text { Siswa belum terlalu } \\
\text { termotivasi saat } \\
\text { mengikuti pembelajaran } \\
\text { karena materi yang } \\
\text { diberikan guru monoton. }\end{array}$ \\
\hline 5 & $\begin{array}{l}\text { Apa upaya yang dilakukan } \\
\text { guru menghadapi } \\
\text { permasalahan yang timbul } \\
\text { dalam pembelajaran servis } \\
\text { forehand panjang } \\
\text { bulutangkis kelas X? }\end{array}$ & $\begin{array}{l}\text { Guru memberikan teknik } \\
\text { pembelajaran servis } \\
\text { forehand panjang } \\
\text { bulutangkis terbatas, } \\
\text { sedangkan siswa hanya } \\
\text { diberikan beberapa }\end{array}$ \\
\hline
\end{tabular}




\begin{tabular}{|l|l|l|}
\hline No. & \multicolumn{1}{|c|}{ Butir Pertanyaan } & \multicolumn{1}{c|}{ Temuan } \\
\hline & & $\begin{array}{l}\text { teknik pembelajaran. } \\
\text { Guru langsung } \\
\text { memberikan materi } \\
\text { servis secara langsung di } \\
\text { lapangan dan langsung } \\
\text { games secara } \\
\text { berpasangan.. }\end{array}$ \\
\hline 6 & $\begin{array}{l}\text { Apakah dibutuhkan } \\
\text { pengembangan teknik } \\
\text { pembelajaran servis } \\
\text { forehand panjang } \\
\text { bulutangkis kelas X? }\end{array}$ & $\begin{array}{l}\text { Guru membutuhkan } \\
\text { teknik pembelajaran } \\
\text { yang bervariasi. Hal ini } \\
\text { bertujuan agar dalam } \\
\text { pembelajaran siswa } \\
\text { antusias dan hasil servis } \\
\text { yang maksimal. }\end{array}$ \\
\hline
\end{tabular}

Pembelajaran servis forehand panjang bulutangkis kelas $\mathrm{X}$ terlihat teknik pembelajaran yang monoton karena guru memberikan materi servis langsung dilapangan menggunakan net dan adanya games. Teknik pembelajaran yang kurang bervariasi menyebabkan kejenuhan pada siswa sehingga tujuan pembelajaran tidak tercapai. Oemar Hamalik (2010) nilai-nilai tujuan dalam pengajaran adalah (1) tujuan pendidikan mengarahkan dan membimbing kegiatan guru dan siswa dalam proses belajar mengajar, (2) Tujuan pendidikan memberikan motivasi positif yang dirangsang dari luar kepada guru dan siswa sehingga pengajaran berlangsung lebih cepat, efisien, dan memberikan kemungkinan untuk berhasil, (3) Tujuan pendidikan memberikan panduan dan petunjuk bagi guru dalam merancang pembelajaran dalam memilih serta menentukan metode dan alat mengajar sehingga akan lebih menarik bagi siswa.

Analisis berikutnya adalah menentukan tujuan, penelitian ini bertujuan untuk mengembangkan teknik pembelajaran servis forehand panjang bulutangkis kelas $\mathrm{X}$ Sekolah Menengah Atas. Adanya pengembangan ini diharapkan dapat menambah jumlah variasi teknik pembelajaran. Subjek penelitian ini menggunakan siswa kelas X karena siswa telah menerima materi saat SMP sehingga dapat mengingat kembali materi servis yang telah diberikan guru. Oleh karena itu harus ada variasi dalam teknik pembelajaran.

\section{2) Design (perancangan)}

Langkah setelah melakukan analisis adalah design (perancangan), penelitian dimulai dengan mengembangkan produk untuk membantu guru PJOK kelas X SMA mengatasi permasalahan yang ditemui dalam teknik servis forehand panjang. Produk pengembangan berupa produk awal dan dalam pengembangannya dilakukan hal yaitu (1) merancang teknik pembelajaran materi servis forehand panjang bulutangkis yang dilakukan dalam pembelajaran siswa putra kelas X SMA, (2) menganalisis teknik dasar servis forehand panjang berdasarkan dalam silabus dan RPP, (3) merancang tujuan pengembangan teknik pembelajaran servis forehand panjang bulutangkis pada siswa putra kelas X SMA. (4) Mengembangkan teknik pembelajaran dasar servis forehand panjangbulutangkis yang sesuai dengan kurikulum.

Sebelum dilakukan uji coba kelompok kecil terhadap produk awal, produk di validasi oleh (1) ahli permainan bulutangkis dan (2) ahli Pendidikan Jasmani, Olahraga, dan Kesehatan. Proses validasi ahli yaitu menilai dan memberi masukan terhadap produk awal. Berdasarkan hal tersebut dilakukan revisi terhadap produk awal. Proses revisi tersebut terus dilakukan sampai produk awal mencapai batas nilai tertentu yang ditetapkan menunjukan bahwa produk awal valid dan layak diujicobakan. Validasi Ahli pada Pengembangan teknik pembelajaran servis forehand panjang bulutangkis pada siswa putra kelas X SMA divalidasi oleh ahli yaitu ahli permainan bulutangkis dan ahli pembelajaran PJOK.

Validasi Ahli Permainan Bulutangkis adalah Juki Hasan merupakan pelatih atlet Sumatera Selatan dan wasit bulutangkis. Hal ini merupakan landasan memilih sebagai ahli permainan bulutangkis. Berikut ini hasil penilaian validasi ahli permainan bulutangkis sebagai berikut:

Tabel 2. Hasil Penilaian Validasi Ahli Permainan Bulutangkis

\begin{tabular}{|c|c|c|c|c|c|}
\hline No & Kode & $\Sigma$ & $\begin{array}{c}\text { Nilai } \\
\text { Maksimal }\end{array}$ & $\begin{array}{c}\text { Presentase } \\
(\boldsymbol{\%})\end{array}$ & Kategori \\
\hline 1 & APB & 19 & 28 & 67,85 & $\begin{array}{c}\text { Cukup } \\
\text { Layak }\end{array}$ \\
\hline
\end{tabular}

Persentase $=$ Jumlah/Nilai Maksimal

$$
\begin{aligned}
& =19 / 28 \times 100 \% \\
& =67,85 \%
\end{aligned}
$$

Validasi tahap pertama diperoleh presentase sebesar $67,85 \%$ (1) sehingga dapat dinyatakan bahwa menurut ahli permainan bulutangkis mengenai pengembangan teknik pembelajaran servis forehand panjang bulutangkis dalam kategori "cukup layak".

Validasi ahli Pembelajaran Penjasorkes (PJOK) adalah Devi Septiara, S.Pd merupakan guru PJOK Sekolah Menengah Atas. Instrumen penilaian validasi ahli pembelajaran PJOK sebagai berikut:

Tabel 3. Hasil Penilaian Validasi Ahli PJOK

\begin{tabular}{|c|c|c|c|c|}
\hline Kode & $\Sigma$ & $\begin{array}{c}\text { Nilai } \\
\text { Max }\end{array}$ & $(\boldsymbol{\%})$ & $\begin{array}{c}\text { Kate } \\
\text { gori }\end{array}$ \\
\hline APB & 39 & 56 & $\begin{array}{c}69, \\
64\end{array}$ & Cukup Layak \\
\hline
\end{tabular}




$$
\begin{aligned}
\text { Persentase } & =\text { Jumlah/Nilai Maksimal } \\
& =39 / 56 \times 100 \% \\
& =69,64 \%
\end{aligned}
$$

Validasi tahap pertama diperoleh persentase sebesar 69,64 \%, (2) sehingga dinyatakan bahwa menurut ahli PJOK teknik pembelajaran servis forehand panjang bulutangkis pada siswa putra kelas X SMA mendapatkan kategori "cukup layak".

\section{3) Development (pengembangan)}

Pelaksanaan pada tahap pengembangan berdasarkan prosedur pengembangan akan dilakukan uji coba, yaitu evaluasi satu-satu dan ujicoba kelompok kecil. Uji coba dilakukan untuk mendapatkan kelayakan buku panduan teknik pembelajaran servis forehand panjang permainan bulutangkis. Evaluasi satu-satu: dilakukan oleh satu orang guru mata pelajaran pendidikan jasmani olahraga dan kesehatan (PJOK). Tujuan evaluasi ini untuk mendapatkan pendapat dari guru terhadap pengembangan teknik pembelajaran servis forehand panjang bulutangkis.

Persentase penilaian terhadap guru PJOK yaitu

$$
\begin{aligned}
& =8 / 10 \times 100 \% \\
& =\mathbf{8 0} \%
\end{aligned}
$$

Berdasarkan hasil one to one yang dilakukan pada guru PJOK diperoleh persentase sebesar $80 \%$ pada kategori "Layak"(3), sehingga dapat diteruskan pada tahap berikutnya yaitu small group.

Uji coba pada kelompok kecil dilakukan pada siswa putra kelas X SMA Negeri 14 Palembang yang dipilih secara heterogen yaitu siswa putra yang berkemampuan tinggi, sedang dan rendah. Siswa putra dipilih oleh guru mata pelajaran PJOK. Tahap ujicoba ini guru PJOK menggunakan pengembangan teknik pembelajaran servis forehand panjang bulutangkis dan dilakukan pada 2 pertemuan pembelajaran (6 JP). Pertemuan pertama menggunakan pengembangan teknik servis forehand panjang dan pertemuan kedua dilakukan evaluasi. Hal ini bertujuan untuk melihat hasil pembelajaran. Penilaian dilakukan dengan menggunakan dua ranah yaitu keterampilan dan sikap. Penilaian digunakan untuk melihat sejauh mana pengembangan teknik pembelajaran ini digunakan oleh guru PJOK dalam pembelajaran dan melihat hasil pembelajaran siswa, sehingga dapat meminimalisir kelemahan atau kekurangan.Berikut ini hasil penilaian terhadap 10 peserta didik yaitu sebagai berikut:

1) Tes Keterampilan Servis Forehand Panjang Bulutangkis

Adapun norma penilaian dalam melakukan servis panjang bulutangkis sebagai berikut:
Tabel 4. Norma Penilaian Servis Panjang Bulutangkis

\begin{tabular}{|c|c|c|}
\hline No & Interval & Keterangan \\
\hline 1 & $31-40$ & Sangat Tinggi \\
\hline 2 & $21-30$ & Tinggi \\
\hline 3 & 20 ke bawah & Rendah \\
\hline
\end{tabular}

Sumber (James Poole, 2007: 23)

Tabel 5. Lembar penilaian yang digunakan dalam melakukan servis forehand panjang bulutangkis siswa Putra kelas X

\begin{tabular}{|c|c|c|c|c|}
\hline No & Subjek & $\begin{array}{c}\text { Nilai } \\
\text { Siswa }\end{array}$ & $\begin{array}{c}\text { Nilai } \\
\text { Max. }\end{array}$ & Kategori \\
\hline 1 & SA & 31 & 40 & $\begin{array}{c}\text { Sangat } \\
\text { tinggi }\end{array}$ \\
\hline 2 & DA & 31 & 40 & $\begin{array}{c}\text { Sangat } \\
\text { tinggi }\end{array}$ \\
\hline 3 & HB & 21 & 40 & Tinggi \\
\hline 4 & MR & 37 & 40 & $\begin{array}{c}\text { Sangat } \\
\text { tinggi }\end{array}$ \\
\hline 5 & LP & 16 & 40 & Rendah \\
\hline 6 & KLA & 17 & 40 & Rendah \\
\hline 7 & GH & 22 & 40 & Tinggi \\
\hline 8 & RT & 36 & 40 & $\begin{array}{c}\text { Sangat } \\
\text { tinggi }\end{array}$ \\
\hline 9 & WET & 33 & 40 & $\begin{array}{c}\text { Sangat } \\
\text { tinggi }\end{array}$ \\
\hline 10 & FR & 31 & 40 & $\begin{array}{c}\text { Sangat } \\
\text { Tinggi }\end{array}$ \\
\hline
\end{tabular}

Tabel 6. Hasil Servis Forehand Panjang Bulutangkis Siswa Putra Kelas X SMA

\begin{tabular}{|c|c|c|c|}
\hline Interval & Frekuensi & Persentase & Keterangan \\
\hline $31-40$ & 6 & $60 \%$ & $\begin{array}{c}\text { Sangat } \\
\text { Tinggi }\end{array}$ \\
\hline $21-30$ & 2 & $20 \%$ & Tinggi \\
\hline $\begin{array}{c}20 \mathrm{ke} \\
\text { bawah }\end{array}$ & 2 & $20 \%$ & Rendah \\
\hline
\end{tabular}

Berdasarkan data yang diperoleh siswa yang lulus KKM adalah 8 siswa yaitu yang berada pada kategori sangat tinggi yaitu 6 siswa $(60 \%)$, kategori tinggi yaitu 2 siswa (20\%) dan yang tidak lulus KKM adalah 2 siswi (20\%). Secara klasikal pembelajaran dapat dikatakan tuntas karena sebanyak 8 siswi $(80 \%)$ dari 10 siswa yang diujicoba melebihi batas KKM, maka produk berupa pengembangan teknik pembelajaran servis forehand panjang dikatakan valid, efektif dan efisien untuk meningkatkan hasil pembelajaran khususnya pada ranah keterampilan.

\section{BAHAN DAN METODE}

Prosedur pengembangan dalam penelitian ini mengunakan metode research and development. Langkah-langkah pengembangan dengan menggunakan model ADDIE. Branch (2009:2) ADDIE merupakan singkatan dari Analysis, Design, Development or Production, Implementation or Delivery and 
Evaluations. Model ADDIE untuk merancang sistem pembelajaran. Adapun rencana kegiatan pada setiap tahap pengembangan teknik pembelajaran servis forehand panjang bulutangkis pada siswa putra Sekolah Menengah Atas SMA Negeri 14 Palembang, yaitu:

\section{Analysis (analisis)}

Analisis kesenjangan kinerja/permasalahan mempunyai tujuan adalah untuk menghasilkan sebuah pernyataan yang berkaitan dengan sebuah masalah, mencari tahu penyebab dan mencari solusi dari kesenjangan atau masalah yang timbul (Branch, 2009:25). Pembelajaran permainan bulutangkis kelas $X$ SMA materi servis forehand panjang terlihat monoton karena guru menampilkan hanya 1-2 jenis teknik pembelajaran. Kurang bervariasi pembelajaran teknik servis forehand panjang yang dilakukan siswa putra langsung di lapangan dan tidak secara bertahap.Hal ini menyebabkan kejenuhan pada beberapa siswa putra sehingga pembelajaran menjadi tidak maksimal. Permasalahan ini menemukan minimnya variasi teknik pembelajaran servis forehand panjang. Branch (2009:33) "Generate goals that respond to performance gaps that are caused by a lack of knowledge and skill" Menentukan tujuan pengajaran adalah untuk menghasilkan sesuatu yang dapat merespon kesenjangan kinerja disebabkan oleh kurangnya pengetahuan dan keterampilan.

Analisis berikutnya menentukan tujuan, tujuan dalam penelitian ini adalah untuk mengembangkan teknik pembelajaran servis forehand panjang bulutangkis pada siswa putra kelas X SMA. Pengembangan ini diharapkan dapat menambah jumlah variasi teknik pembelajaran. Langkah selanjutnya yang dilakukan adalah menganalisa siswaputra. Warsita (2008:228) analisis kebutuhan dilakukan untuk mengetahui kompetensi yang dimiliki siswa dapat diketahui melalui proses analisis karakter peserta didik meliputi (a) karakteristik khusus seperti pengetahuan, keterampilan, dan sikap awal peserta didik. (b) karakteristik umum, seperti kelas berapa, jenis kelamin apa, latar belakang budaya apa, kebiasaan dan sebagainya. Subjek penelitian pengembangan ini menggunakan siswa putra kelas X SMA.

\section{Design (perancangan)}

1) Pembuatan Produk

Langkah setelah melakukan analisis adalah design (perancangan) dimulai dengan mengembangkan produk untuk membantu guru Pendidikan Jasmani, Olahraga, dan Kesehatan (PJOK) SMA kelas X mengatasi permasalahan yang ditemui dalam pembelajaran servis forehand panjang. Produk pengembangan masih berupa produk awal dan dalam pengembangannya dilakukan hal-hal sebagai berikut: merancang pembelajaran materi permainan bulutangkis yang dilakukan dalam pembelajaran untuk siswa putra kelas X SMA, kemudian menganalisis teknik pembelajaran servis forehand panjang sesuai dengan silabus. Hal ini bertujuan agar produk yang dirancang tidak melenceng dari panduan silabus yang ada. (c) merancang tujuan pengembangan teknik pembelajaran dasar bulutangkis pada siswa putra kelas X SMA, dan (d) mengembangkan teknik pembelajaran dasar servis forehand panjang sesuai dengan kurikulum.

2) Validasi Ahli dan Revisi

Produk yang sudah selesai dikembangkan akan dilakukan validasi oleh para ahli. Validasi desain yang terdiri dari uji ahli desain dan uji ahli isi/materi pembelajaran akan dilakukan oleh tim ahli yaitu (a) materi bulutangkis, dan (b) guru PJOK. Proses validasi ahli yaitu menilai dan memberi masukan terhadap produk awal sampai mencapai batas nilai tertentu yang ditetapkan. Hal ini menunjukan bahwa produk awal valid dan layak diujicobakan.

\section{Development (Pengembangan)}

Berdasarkan prosedur pengembangan maka pelaksanaan pada tahap pengembangan ini akan dilakukan uji coba yaitu evaluasi satu-satu dan ujicoba kelompok kecil. Uji coba dilakukan untuk mendapatkan kelayakan teknik pembelajaran servis forehand panjang bulutangkis. Evaluasi satu-satu ini dilakukan oleh 1 orang guru PJOK. Tujuan evaluasi ini adalah untuk mendapatkan pendapat guru mata pelajaran PJOK terhadap teknik pembelajaran servis forehand panjang bulutangkis. Uji coba kelompok kecil dalam tahap ini dilakukan dengan mengujikan produk pada 10 orang siswa putra kelas X SMA Negeri 14 Palembang yang dipilih secara heterogen yaitu siswa yang berkemampuan tinggi, sedang dan rendah. Setelah dilakukan uji kelompok kecil, 10 orang siswa tersebut diminta untuk memberikan tanggapan atau pendapat terhadap teknik pembelajaran servis forehand panjang bulutangkis yang dikembangkan sebagai evaluasi guna meminimalisir kelemahan atau kekurangan terhadap produk dan apabila masih terdapat kekuranganmaka akan dilakukan revisi kembali agar produk dapat diimplementasikan pada kelas sesungguhnya.

\section{Implementation (Implementasi)}

Tahap development(pengembangan) dilakukan revisi produk dan dinyatakan layak maka pengembangan teknik pembelajaran servis forehand panjang bulutangkis akan di implementasikan pada kelas yang sesungguhnya. Produk berupa pengembangan teknik pembelajaran servis forehand panjang bulutangkis diimplementasikan pada siswa putra kelas X SMA Negeri 14 Palembang.

\section{Evaluation (Evaluasi)}


Tahap akhir proses penelitian pengembangan ini adalah melakukan evaluasi terhadap produk yaitu pengembangan teknik pembelajaran servis forehand panjang bulutangkis. Robert Maribe Branch (2009) "The purpose of the evaluate phase is to assess the quality of the instructional products and processes, both before and after implementation". Tujuan dari tahap evaluasi ini adalah untuk melihat atau menaksir kualitas produk pembelajaran dan proses, yang keduanya dapat dilakukan sebelum dan sesudah implementasi.

Teknik analisis data merupakan cara untuk mengetahui hasil penelitian yang dilakukan. Analisis data mencakup seluruh kegiatan mengklarifikasi, menganalisa, memakai dan menarik kesimpulan dari semua data yang terkumpul dalam tindakan. Setelah data terkumpul, maka data tersebut akan diolah. Teknik analisa data yang dilakukan pada penelitian ini adalah teknik analisa kuantitatif yang bersifat penilaian menggunakan angka. Persentase dimaksudkan untuk mengetahui status sesuatu yang dipersentasekan dan disajikan tetap berupa persentase. Rumus perhitungan kelayakan menurut Sugiyono (2013) adalah sebagai rumus: Skor hitung (SH) di bagi Skor Kriteria (SK) atau Skor Ideal.

Hasil perhitungan data selanjutnya dibuat dalam bentuk persentase dengan dikalikan $100 \%$, setelah diperoleh persentase dengan rumus tersebut, selanjutnya kelayakan pengembangan teknik pembelajaran servis forehand panjang bulutangkis siswa putra kelas X SMA dalam penelitian pengembangan ini digolongkan dalam empat kategori kelayakan dengan menggunakan Skala sebagai tabel 6 .

Tabel 6. Kategori Kelayakan

\begin{tabular}{|c|l|}
\hline Skor dalam persentase & Kategori Kelayakan \\
\hline$<40 \%$ & Tidak Baik/ Tidak Layak \\
\hline $40 \%-55 \%$ & Kurang Baik/Kurang Layak \\
\hline $56 \%-75 \%$ & Cukup Baik/Cukup Layak \\
\hline $76 \%-100 \%$ & Baik/Layak \\
\hline
\end{tabular}

Angket yang digunakan dalam peneitian ini adalah angket penilaian atau tanggapan dengan bentuk jawaban dan keterangan penilaian menurut Arikunto (2010) , yaitu.(1)sangat tidak setuju/sangat tidak layak, (2)Tidak sesuai/tidak layak, (3) Sesuai/layak, (4) Sangat sesuai/sangat layak.

\section{PEMBAHASAN}

Pukulan servis forehand panjang bulutangkis dilakukan dengan memukul shuttlecock menggunakan raket ke belakang bidang permainan lawan. Servis ini sering dilakukan oleh pemain tunggal. Permainan tunggal pukulan servis panjang yang tinggi dan dalam sangat penting dilakukan. Pukulan shuttlecock saat melakukan servis panjang harus tepat untuk dapat menghasilkan angka. Pukulan yang terlalu keras akan menyebabkan shuttlecock keluar lapangan sehingga lawan akan mendapatkan nilai. Begitu jugapukulan yang terlalu lemah. Berdasarkan data yang diperoleh siswa yang lulus KKM adalah 8 siswa yaitu yang berada pada kategori sangat tinggi yaitu 6 siswa (60\%), kategori tinggi yaitu 2 siswa (20\%) dan yang tidak lulus KKM adalah 2 siswi (20\%). Secara klasikal pembelajaran dapat dikatakan tuntas karena sebanyak 8 siswi $(80 \%)$ dari 10 siswa yang diujicoba melebihi batas KKM, maka produk berupa pengembangan teknik pembelajaran servis forehand panjang dikatakan valid, efektif dan efisien untuk meningkatkan hasil pembelajaran khususnya pada ranah keterampilan.

Berdasarkan data yang diperoleh siswa yang lulus KKM adalah 8 siswa yaitu yang berada pada kategori sangat tinggi yaitu 6 siswa (60\%), kategori tinggi yaitu 2 siswa (20\%) dan yang tidak lulus KKM adalah 2 siswi (20\%). Secara klasikal pembelajaran dapat dikatakan tuntas karena sebanyak 8 siswi $(80 \%)$ dari 10 siswa yang diujicoba melebihi batas KKM. Siswa putra dengan kategori tinggi dan rendah saat pelaksanaan tes kemampuan servis panjang perlu perhatian khusus untuk dapat lebih meningkatkan latihan agar tercapai kemampuan yang baik. Latihan servis forehand panjang perlu diberikan lebih banyak kepada siswa yang kategorinya tinggi dan rendah agar lebih meningkat kemampuan. Kemampuan servis yang meningkat diharapkanpermainan bulutangkis juga mengalami peningkatan. Siswa dengan kategori sangat tinggi perlu ditingkatkan lagi latihannya agar tercapai kemampuan yang lebih baik lagi.

\section{KESIMPULAN}

Mata pelajaran dalam Pendidikan jasmani, olahraga, dan kesehatan (PJOK) yaitu terdapat materi permainan bulutangkis. Materi yang diajarkan dalam bulutangkis salahsatunya adalah servis forehand panjang. Servis sangatlah penting karena awal mula bermain dan dapat menghasilkan poin. Pemilihan teknik pembelajaran yang tepat sangat dibutuhkan untuk meningkatkan pencapaian hasil belajar siswa. Teknik pembelajaran dalam penerapannya dilakukan sesuai dengan kebutuhan siswa. Hasil penelitian ini berupa buku servis forehand panjang bulutangkis. Berdasarkan hasil validasi ahli permainan bulutangkis diperoleh presentase sebesar $67,85 \%$ dalam kategori "cukup layak". Validasi dari ahli Pendidikan Jasmani, Olahraga dan Kesehatan (PJOK) diperoleh persentase sebesar 69,64 dalam kategori "cukup layak". Pengembangan teknik pembelajaran servis forehand panjang dapat digunakan untuk materi bulutangkis.

\section{SARAN}

Adapun saran dalam penelitian ini adalah bagi guru PJOK dapat menambahkanvariasi teknik pembelajaran servis forehand panjang bulutangkis untuk siswa kelas $\mathrm{X}$ SMA sehingga lebih menarik. Bagi siswa dapat memberikan motivasi dan hasil belajar yang baik. 


\section{DAFTAR PUSTAKA}

Arikunto, S. 2010. Prosedur penelitian : Suatu Pendekatan Praktik. (Edisi Revisi). Jakarta : Rineka Cipta.

Halik, Abdul. Inovasi Teknik Pembelajaran Pendidikan Agama Islam pada SMA Model Negeri 3 Palu. Jurnal Studia Islamika, 10 (1), 43-73.

Hamalik, Oemar. 2010. Kurikulum dan Pembelajaran. Jakarta: Bumi Aksara.

Juhanis. 2012. Hubungan Kelentukan Pergelangan Tangan dan Ketepatan dengan Kemampuan Servis Pendek pada Permainan Bulutangkis Siswa SMA Negeri 1 POMALAA Kabupaten Kolaka. Jurnal ILARA, 3 (2), 10-20.

Nurhasan, dkk. 2015. Bulutangkis. UNESA University Press.

Paturusi, Achmad. 2012. Managemen Pendidikan Jasmani dan Olahraga. Jakarta: Rineka Cipta.

Poole, James. 2007. Belajar Bulutangkis. Bandung: CV. Pionir Jaya.

Purnama, K. S. 2010. Kepelatihan Bulutangkis Modern. Surakarta: Yuma Pustaka.

Undang - undang RI No 3 Tahun 2005 tentang Sistem Keolahragaan Nasional. Kementrian.Negara Pemuda dan Olahraga Republik Indonesia.

Uno, Hamzah B. 2009. Model Pembelajaran Menciptakan Proses Belajar Mengajar yang Kreatif dan Efektif. Jakarta: PT Bumi Aksara

Yane, Stephani. 2016. Peningkatan Servis Panjang Bulutangkis melalui Model Problem Based Learning. Jurnal Pendidikan Olahraga, 5 (2), 165174.

Warsita, Bambang. 2008. Teknologi Pembelajaran Landasan \& Aplikasinya. Jakarta: Rineka Cipta.

\section{UCAPAN TERIMA KASIH}

Ucapan terima kasih kepada Rektor Universitas Sriwijaya, Ketua Program Studi Penjaskes FKIP

Universitas Sriwijaya, Mahasiswa, Kepala SMA Negeri 14 Palembang, Guru PJOK, dan pihak yang terlibat dalam menyelesaikan penelitian ini. 